\title{
The Relationship Between Learning Orientation And Business Performance And The Moderating Effect Of Competitive Advantage: A Service Organization Perspective
}

Louis A. Martinette, University Of Mary Washington, USA Alice Obenchain-Leeson, Averett University, USA

\begin{abstract}
This study examines the influence of learning orientation on business performance (the achievement of sales and profit objectives) in the context of pure service. The conceptual framework used in this research has been drawn from marketing, finance, and organizational behavior theory. Specifically, relationships related to learning orientation, sources of competitive advantage, and business performance have been identified. This research develops and tests a framework about learning orientation and its consequences in an organization. Specifically, this study focused on several research questions, including: 1) "Is there a relationship between learning orientation and business performance in terms of the achievement of sales and profit objectives in pure service and service-reliant organizations?", 2) "Is there a relationship between learning orientation and competitive advantage in pure service and service-reliant organizations?", and 3) "Does competitive advantage moderate the relationship between learning orientation and business performance in pure service and service-reliant organizations?"

A survey-based research methodology is used to explore these research questions and pertinent findings reported in the light of previous studies (Martinette, 2006, Martinette and ObenchainLeeson, 2010).

The findings of this study suggested that competitive advantage moderates the relationship between learning orientation and business performance in pure service and service-reliant organizations.
\end{abstract}

Keywords: Marketing; Management; Organizations; Learning; Learning Orientation; Learning Organizations; Competitive Advantage; Pure Service Businesses; Service-reliant Organizations

\section{INTRODUCTION}

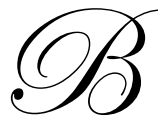

oth the popular business press and scholarly research consistently identify service as an integral part of most business models. Scott Adams (2011), creator of the comic strip "Dilbert", recently noted in a Wall Street Journal article (June 18, 2011), "If you could design a virtual vacation to be $75 \%$ as good as the real thing for $30 \%$ of the cost, you'd have a winning business model."

Ron Johnson, the architect of the intangible appeal of the Apple Retail Stores, was named CEO of the traditional old-line retailer, J. C. Penney, and the retailer's stock jumped almost 18\% (Ovide, 2011). Ovide (2011), referring to Johnson as the man who would "sprinkle some of that Apple fairy dust," was likely referring to the 
intangible experience that goes with the willingness to pay more for the innovative high tech products that one can acquire.

When one considers the success of Starbucks, Pandora, iTunes, and other similar products and firms, service continues to be a value-added component of competitive advantage that offers tangible results that are more often than not based on the intangible appeal of the buying process. Gronroos (2000) suggests that these organizations operate from a "service perspective", meaning that the role of service components in the organization's offering is seen as strategic. Gronroos (2000) further suggests that strategic perspective requires focus on the total service offering, which is defined as an organizational offering that contains physical product components, service components, information, and personal attention. Inherent in this definition, one clearly assumes the need for internal collaboration, mutual exchange of information with customers, and a chain of value-delivering activities that are well coordinated internally. Service offerings, by their nature, are often characterized as inseparable meaning that the consumption and production of services involve the producer and the seller at the same time. For a firm to be able to deliver value in service industries then seems to suggest dependence on organizational learning as it focuses on how to effectively satisfy customers' expressed and latent needs by designing and delivering new products, services, and methods of doing business (Slater \& Narver, 1995; Lopez, Peon and Ordas; 2005). Therefore, it would seem plausible that organizational learning likely holds the key to success in service organizations.

Stata (1989) emphasized the importance of learning in organizations when he strongly suggested that learning is a major source of competitive advantage, when he asserts, "In fact, I would argue that the rate at which individuals and organizations learn may become the only sustainable competitive advantage, especially in knowledge intensive industries" (p. 64).

Organizations often fail to optimize skills and, as a result, they fail to optimize their abilities, which involves integrating disciplines like marketing, production, services, etc. (Martinette \& Obenchain-Leeson, 2010).

The twentieth century has seen dramatic changes in business, as noted by Kiernan (1993) when he indicated that during that time, the measure of competitive advantage has shifted four-fold from price to volume to quality, to speed, and to mass customization. Each shift represented a nod back to the predecessor and a look to the future deliverables that included new challenges for businesses, promising, according to Kiernan (1993) "... a more promising twenty-first century" where the "competitive ante" has been "raised even higher." (p. 8)

\section{STATEMENT OF THE PROBLEM}

A well-crafted vision for an organization, communicated by its leaders (Slater \& Narver, 1995), indicates that such leaders are committed to learning and that learning likely provides the key to gaining a competitive advantage (Sinkula, Baker, Noordewier, 1997). According to DeLong and Nanda (2003) services account for a large portion of the U.S., as well as the world economy and go on to say "To ensure that value is generated, Professional Service Firm (PSF) leaders must ensure that the economies of working together (scale, scope, complementarities, shared aspirations) outweigh the diseconomies (complexity, dissension, politicking, strife)" (p. xv). The ability to understand and retain the culture and attitude that led a firm to a competitive advantage could be useful in the longterm maintenance of a competitive advantage. Thus, understanding the role competitive advantage plays in the learning orientation-business performance relationship could provide insight for managers of service-reliant firms that would be useful in reinforcing their foundation through learning.

Gronroos (2008) suggested that value creation is the center of most discussions about service that can offer marketing something new for the customer in terms of perspective or logic. There are three different aspects to service in the literature as identified by Gronroos (2008), including "service as an activity; service as a perspective on customer's value creation; and service as a perspective on the provider's activities (business logic)." (p. 300) For the customer, examples of service include a dry cleaner preparing dress shirts so that one can go to their office, lunch provided by a restaurant, etc. (Gronoos, 2008). On the other hand, internally one may consider the complex nature of the concept of a learning organization and the service it can provide within the organization, as observed by Bolman and Deal (2003): "At home you flip a switch and the light goes on. In an organization, you flip a switch 
and nothing happens until long after you leave the room—or a toilet may flush in a building 10 miles away. You are still in the dark, and the user of the toilet is unpleasantly surprised. To understand what is going on, you need to master the system's complex circular causality.” (p. 28)

Service within a learning orientation represents an organizational characteristic that reflect the value that a firm places on constantly challenging the assumptions that frame the organization's relationship with its environment, both internal and external. It is also important for firms to make changes strategically as changing world does not mean "timeless principles" should be discounted. As Collins (2001) notes: "While the practices of engineering continually evolve and change, the laws of physics remain relatively fixed." (p. 15)

The relationship between a learning organization and business performance has been found to be positive (Baker \& Sinkula, 1999) in a wide range of business types. Business performance, which is critical to organizations, represents a measurement of its chances for long-term survival. Research on learning orientation, competitive advantage, and firm performance is extensive, but several open questions remain.

First, research has indicated that market orientation is a source of competitive advantage while learning orientation acted as an internal moderator (Baker \& Sinkula, 1999). It would be useful to understand the moderating influence of the sources of competitive advantage on the relationship between learning orientation and business performance.

Second, market oriented processes are considered necessary for the maintenance of competitive advantage but are not sufficient in and of themselves (Baker \& Sinkula, 1999). Researchers have found that it is necessary to have a strong learning orientation for a firm to remain on a solid course toward market dominance and financial success (Baker \& Sinkula, 1999). However, the existence of successful processes often becomes a barrier to openminded inquiry and goal attainment. Mental models must be managed by an open-mindedness that considers and reconsiders assumptions about how an organization works (Senge, 1992; Sinkula et al, 1997).

Third, Sinkula et al. (1997) suggest that research is needed that considers the relationship between learning orientation and competitive advantage from different perspectives. As noted above, some consider learning orientation to be a major source of competitive advantage (Kiernan, 1993; Stata, 1989). On the other hand, learning can provide an understanding of the nature of an organization's strengths and weaknesses, providing managers with a greater ability to exploit their firm's competitive advantage.

Fourth, research has been proposed that could examine separately, the effects and the interaction of individual, organizational, and technical aspects of how market information systems work (Moorman \& Rust, 1999). The research presented in this paper identifies the influence of an organization's market responsiveness to both customers and competitors on learning orientation and business performance in pure service businesses.

This brief literature review and the conceptual model (Figure 1) provide the basis for the theoretical relationships that were examined in this study. These gaps in the literature suggest how competitive advantage influences the effectiveness of a learning orientation and its relationship to firm performance objectives in pure service businesses, while advancing the following research questions, leading to the hypotheses that were tested:

1. Is there an association between learning orientation and business performance - the achievement of sales and profit objectives in pure service and service-reliant organizations?

2. Is there an association between learning orientation and competitive advantage in pure service and servicereliant organizations?

3. Does competitive advantage moderate the relationship between learning orientation and business performance in pure service and service-reliant organizations?

\section{JUSTIFICATION AND RATIONALE}

Learning orientation has been defined and developed extensively in the literatures of sociology, psychology, and anthropology, which suggest a rather broad approach to research (Slater \& Narver, 1995). In the 
marketing literature, learning orientation has been looked at as a moderating influence on the market orientation and business performance relationship (Baker \& Sinkula, 1999). Learning orientation has also been shown to contribute to superior results in new product success, higher customer-defined quality, and superior performance and profitability (Slater \& Narver, 1995).

This study adds to the literature of learning orientation and competitive advantage in several ways, supporting the research challenge of Slater and Narver (1995) that the development of "knowledge about specific management practices and the way they should be configured to provide solid guidance" (p. 72) in building learning oriented organizations that focus on pure service and service-reliant markets. This context is important for a variety of reasons. One, service firms are likely to utilize the concepts of organizational learning in order to provide high service quality and promote best performance (Ussahawanitchakit, 2008). Two, the nature of an organizational learning culture tends toward a better understanding of customer needs as well as expectations that provide insight into the types of services that may be of interest to customers (Ussahawanitchakit, 2008).

More broadly, the domain of learning orientation remains highly relevant as a domain of academic inquiry for a variety of reasons. First, executives and managers are in danger of being overwhelmed by the available sources of information that include online Internet search engines, internal sources of information and intelligence, marketing research reports and surveys, and an explosion of technical literature (Cravens \& Piercy, 2006). Research has suggested that to maximize firm performance it is necessary that learning organizations 1) provide the necessary values like open-mindedness, shared vision/purpose, and commitment to learning; 2) recognize customer's needs and wants; 3) know when to replicate organizational knowledge and when to interpret it (Baker \& Sinkula, 1999; Slater \& Narver, 1995). In turbulent markets, organizations must use learning processes to create behavior change that leads to performance improvement (Slater \& Narver, 1995).

Second, competitive advantage has been defined loosely as distinctive activities that a firm does better than competitors (Porter, 1985) and the more an organization learns about those resources likely improves the chances to better coordinate the efforts of employees to enhance their core capabilities that lead to competitive advantage.

Third, this research provides valuable information to the practitioner, who is responsible for delivering both sales and profits from the organizational culture provided. The financial investment in learning is quite high and it is important to understand what makes it effective, as it is critical that managers have the ability to deliver to business performance expectations.

Sensing, learning, and acting on environmental forces enhance a firm's potential for competitive advantage and superior financial performance (Ramaswami , Bhargava, Srivastava, 2004). Kaplan and Norton (1996) posited that a company measure learning and feedback as an important link to financial performance.

\section{PREVIOUS RESEARCH AND CONCEPTUAL FRAMEWORK}

This study investigated the research questions using a convenience sample of executives and managers from a range of pure service companies in the United States. Representation included individuals from both public and private companies across a variety of industries that were determined to be either pure service or service-reliant organizations. Pure service organizations were self-described as organization's whose primary offering is an intangible experience/offering. Service-reliant organizations were self-identified as organizations whose organizational offering contains both physical product components and service components.

Individuals from all organizational disciplines were surveyed in order to capture the wide range of views present in the firms. This was important because one of the critical components being measured is shared vision and purpose, which is an organization wide trait.

Using the same data set as Martinette (2006) and Martinette and Obenchain-Leeson (2010), this research tested the earlier model incorporating pure service and service-reliant firms (see Figure 1). 


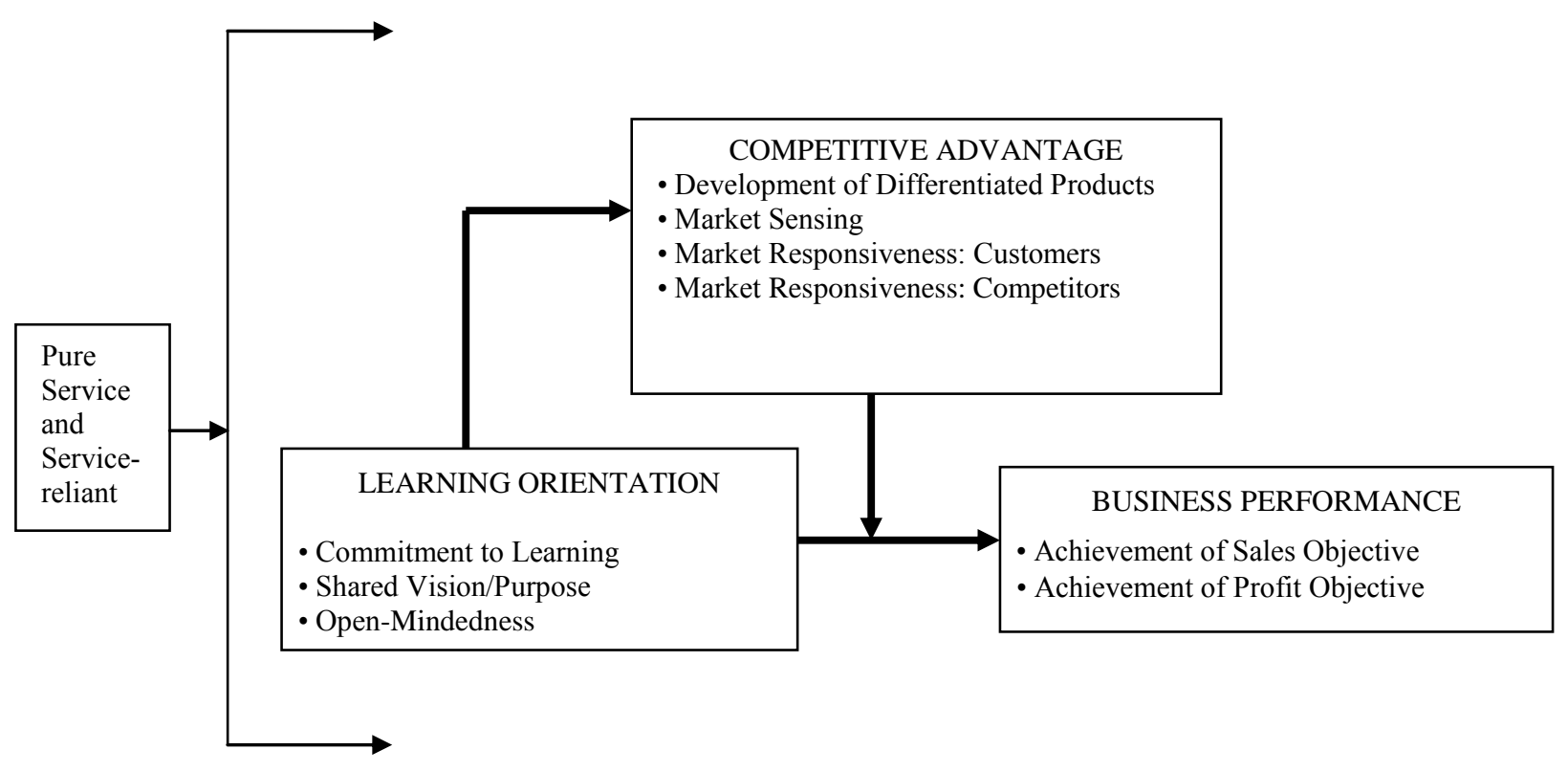

Figure 1: Conceptual framework of Learning Orientation (Sinkula, Baker, Noordewier, 1997), Competitive Advantage (Ramaswami, Bhargava, Srivastava, 2004), and Firm Performance (Vorhies and Morgan, 2003)

Martinette (2006) conducted a study of a model (Figure 1) positing that the achievement of business performance measures of sales and profit are influenced by how effectively a firm's sources of competitive advantage moderates learning orientation. First, the study assessed the influence of learning orientation on business performance-the achievement of sales and profit objectives. Second, the study looked at the moderating effect of competitive advantage on that relationship, providing insight into the learning orientation and business performance relationship.

There were a number of limitations that influenced the generalizability of the Martinette (2006) study. First, the sample selection was based on a convenience sample, which is often used for exploratory work (Zikmund, 2003), rather than a random probability sample. Martinette (2006) recommended that additional research could be conducted using a random probability sample. Second, the sample represented a limited number of companies in limited industries. Third, the sample represented a number of narrowly focused functional areas, with sales and administrative people accounting for $44.3 \%$ of the respondents. No other functional area exceeded $10 \%$ of the respondents, with accounting representing 9.5\%. Fourth, approximately $76.9 \%$ of the respondents were highly placed executives. A broader representation of lower level functional employees may have provided different results. Fifth, the sample size was not large enough to make significant comparisons among the subgroups. Sixth, pure service firms were combined with product and product/service organizations. According to DeLong and Nanda (2003) Professional Services Firms (PSFs) are distinguished by having knowledge, experience, and the reputation of their skilled workers as their primary assets, thus relying on intangibles as a foundation for competitive advantage. Thus, the results of this study should be considered indicative rather than definitive based on these limitations.

The value of professional services, because they are intangible, is often difficult to measure and its providers are often "highly skilled people" (p. xv) with multiple affiliations, including the services organization as an employee or as an owner (DeLong \& Nanda, 2003). PSF leaders, according to DeLong and Nanda (2003), often "depend on their employees for asset development and service delivery" (p. xv) and their success is often driven by the fact that "Competitive advantage in the service business is usually rooted in the ability to attract, nourish, and motivate the best talent in the labor market." (p. xv) Therefore, these "service-reliant" firms can be said to depend on a commitment to learning, a shared vision, and open-minded inquiry for their very survival. 
Service-reliant firms are likely to use organizational learning as a strategy for providing high quality service and achieve best performance (Ussahawanitchakit, 2008). The "inseparability" of production and consumption for buyers and sellers make the pure service domain ripe for such inquiry, which seems to confirm Gronroos' (2008) suggestion that buyers and sellers, in pure service domain are co-creators of value. Furthermore, it would be logical to consider that an effective learning orientation within a firm would, in fact, result in and be affected by the competitive advantage of the firm.

Previous and similar studies also have identified a positive relationship between learning orientation and competitive advantage (Day, 1994b). Slater and Narver (1995) suggest that future research on learning orientation involve examining its relationship to competitive advantage and superior performance. Thus, the primary contribution of this study was to examine the moderating influence of sources of competitive advantage on the learning orientation and firm performance relationship in pure service and service-reliant organizations. As of this writing, no specific studies of this nature have been found.

Researchers have identified sources of competitive advantage in the context of differentiation (Porter, 1985; Ramaswami et al., 2004), market-sensing, (Day, 1991, 1994a; Day \& Wensley, 1988; Ramaswami et al., 2004), and market responsiveness to customers and competitors (Ramaswami et al., 2004). There has been a historical tradition in research that suggests that issues in the marketing environment moderate the effectiveness of organizational characteristics (Slater \& Narver, 1994a). However, it is unclear whether this suggestion is meaningful in the context of all organization types, or specific ones such as service organizations. This study will show whether or not the sources of competitive advantage moderate the relationship between learning orientation and firm performance in service organizations.

Market-driven organizations have mastered the abilities to sense (Figure 1) what their customers need and link those needs to gaining an advantage with their customers (Day, 1994a). Another source of competitive advantage comes from knowing customers better than competitors and being responsive (Figure 1) to both (Woodruff \& Gardial, 1996). Furthermore, an organization's competitive advantage also evolves from an ability to learn how to provide differentiated (see Figure 1) products that are difficult for a competitor to replicate (Slater \& Narver, 1995).

Sinkula, Baker, and Noordewier (1997) suggest that "organizations that are competent learners" are known as learning organizations. Learning has been studied for many years (Argyris, 1977 \& 1991; Fiol \& Lyles, 1985; Huber, 1991; Levitt \& March, 1988; Stata, 1989) resulting in a wide range of definitions that view organizational learning as a time focused process that relates to the acquisition of knowledge and performance improvement (Garvin, 1993). Many of the definitions suggest that learning is dependent on either behavioral change or that "new ways of thinking" are sufficient (Garvin, 1993) as shown in the following definition: "A learning organization is an organization skilled at creating, acquiring, and transferring knowledge, and at modifying its behavior to reflect new knowledge and insights" (p. 80). The definition begins with the idea that innovation is necessary if learning is to occur (Garvin, 1993). The return on investment from effectively utilizing information capabilities happens when managers interpret learning into actions that lead to competitive advantage in markets (Woodruff, 1997).

The conceptual framework used in this research was drawn from marketing, finance, and organizational behavior theory. Specifically, relationships related to learning orientation, sources of competitive advantage, and business performance were identified in a way not previously studied (Figure 1). The discussion that follows develops the theories of learning orientation (the core theory of this paper), competitive advantage, and identifies key business performance measures.

\section{LEARNING ORIENTATION}

Senge (1990) posits that the basic definition of a learning organization is one that that constantly expands its ability to affect and create its future by considering the five disciplines of a learning organization to be an ensemble that incorporates: Team Learning, Personal Mastery, Mental Models, Building Shared Vision; and Systems Thinking. The operationalization of learning orientation recommended for this study includes commitment to learning, shared vision/purpose, and open-mindedness; this operationalization has demonstrated reliability and validity (Sinkula et al., 1997). 


\section{Commitment to Learning}

Ussahawanitchakit (2008), in his study of organizational learning cultures on service quality and performance in accounting firms, indicated that learning orientation involves the sharing of information about customer needs, market changes, and competitor actions that assist with the development of products that position a firm for a competitive advantage. Leaders should communicate a well-crafted vision for an organization (Slater \& Narver 1995). This would indicate that such leaders are committed to learning and that learning provides the key to gaining a competitive advantage (Sinkula et al., 1997). The primary determinant to gaining a competitive advantage is a high rate of individual and organizational learning (Stata, 1989).

The center of gravity in a learning orientation is expressed by the value placed on learning by an organization (Sinkula et al., 1997). An organization that values learning has a commitment to learning (Sinkula et al., 1997). Learning organizations are different from more traditional organizations because they are typically led by individuals who are committed to changing the way a business operates in an effort to improve productivity, achieve higher levels of success, and personal satisfaction (Senge, 1990). The intensity of learning is the way learningoriented organizations attempt to understand the causes and effect of their actions (Sinkula et al., 1997). Organizational learning, unlike individual learning, depends on shared insights and past knowledge (Stata, 1989) and does not just happen in a vacuum.

\section{Shared Vision/Purpose}

Shared vision and purpose influences the direction of learning by providing a focus for learning that helps in the understanding of what needs to be learned while the intensity of learning is the way learning oriented organization attempts to understand the causes and effect of their actions (Sinkula et al., 1997). Slater and Narver (1994b) state that learning organizations recognize that “...synergy among components that leads to learning and superior performance and provides the basis for a competitive advantage that is very difficult for competitors to imitate" (p. 238) while an internal environment that encourages learning also influences competitive advantage that leads both customers and competitors (Baker \& Sinkula, 1999).

Organizations that view the information generation and dissemination power of market information processing systems as the mechanism for learning are making a link to knowledge acquisition (Sinkula et al., 1997) and firm performance (Kohli \& Jaworski, 1990). Sinkula et al. (1997) suggest that information generation is probably the most important element of market information processing, and without it, there is no opportunity for the organization to gain knowledge of its customer and competitor environments. Acquired information must be distributed to decision-makers efficiently if they are to have the opportunity to use it effectively (Sinkula et al., 1997). As such, researchers have concluded that a learning orientation influences the satisfaction of an organization with how proactive learning occurs, thereby affecting the information that is ultimately used, accepted or rejected, interpreted, and evaluated (Day 1991, 1994b; Senge, 1990; Sinkula et al., 1997).

\section{Open-Mindedness}

A learning organization requires open-mindedness to reflect on the past and view the future with the ability to change. The knowledge gained from learning represents only half of the solution, with the other half coming from unlearning (Hamel \& Prahalad, 1994). The first step in unlearning is a proactive approach to challenging long established routines, assumptions, and beliefs (Sinkula et al., 1997). The way that customers define value evolves into the guiding force for deciding what to improve (Woodruff \& Gardial, 1996) and knowing how to improve it. Organizational learning and the innovations that can result from the knowledge gained, helps a company create a future by unlearning its past (Hamel \& Prahalad, 1994), opening the door to new view of markets and what that translates into for the customer in terms of the processes that are used to provide a competitive advantage. An organization's employees who are in contact with customers (both old and new) will gather information about competitors and problem solving, each of which provides ample opportunity to learn new ideas (Hamel \& Prahalad, 1994). 
Learning orientation is an organizational characteristic that reflects the value that a firm places on constantly challenging the assumptions that frame the organization's relationship with its environment, relative to both customers and competitors.

\section{COMPETITIVE ADVANTAGE}

A firm uses its unique resources to create offerings that have superior value to customers (Ramaswami et al., 2004). The resources used to develop market offerings include sources of competitive advantage (differentiation, sensing, and customer and competitor responsiveness) that can be exploited and enhanced by higher-order learning (Hunt \& Morgan, 1996; Ramaswami et al., 2004). The sources of competitive advantage construct of Ramaswami et al. (2004) was recommended for this study and is illustrated in Figure 1, and has demonstrated reliability and validity.

\section{Responsiveness: Customer and Competitor}

Organizations with market insights are successful because they know why they succeeded in the past and they understand current structures, relationships, and motivations in their markets (Day, 1991). According to Day (1991), there are three critical and converging trends that explain the importance of learning to marketers:

- $\quad$ The rapid pace of change

- $\quad$ The amount of available information

- $\quad$ The need for organizations to be proactive in the development of timely and coherent strategies that address markets

To provide management with a framework for diagnosing competitive superiority, Day and Wensley (1988) suggest "evaluate the current approaches and methods within an organizing framework that clarifies the nature of competitive advantage," (p. 1) by looking at: 1) the merits of management judgments of strengths and weaknesses and how they compare with measures of market share; 2) comparisons of the relative size of resource commitments; and 3) customer comparisons of competitors on their purchase criteria. The Day and Wensley (1988) framework identifies two distinct approaches: First, customer focused: "Start with detailed analysis of customer benefits within end-use segments and work backward from the customer to the company to identify the actions needed to improve performance." (p. 1) Second, competitor focused: "Based on direct management comparisons." (p. 1) The primary objective of Day and Wensley's (1988) research was to use this framework as a vehicle for "proposing a process that can be used to ensure a thorough and balanced assessment of the reasons for the competitive position of a business" (p. 2).

\section{Differentiation}

Differentiated products are the result of a myriad of competencies that enhance competitive advantage (Ramaswami et al., 2004). Many sources of competitive advantage include activities that companies must perform in order to compete, including order processing, meeting with customers, assembling products, and employee training (Porter, 1985). Inward looking companies would isolate activities from resource capabilities (Day, 1994a; Porter, 1985). The activities of the components of order processing, meeting with customers, assembling products, and employee training are the assets that facilitate a firm's competitive advantage (Porter, 1985).

\section{Market Sensing}

Day (1994a) suggests that a firm that is market-driven has the ability to sense events and trends in their markets and act accordingly. Market-driven firms capture the knowledge of organizational members across the spectrum, from front-line sales to the CEO; including a "learning process" that asks relevant questions at the right time (Day, 1994a). A learning orientation cannot be complacent and should never stop searching for ways to improve products, eliminate poor quality, and continually excel at customer service (Day, 1994a). The faster an organization can learn about their markets, while responding appropriately to that knowledge, the better they are positioned for competitive advantage (Day, 1991; deGues, 1988; Senge, 1990; Slater \& Narver, 1994a). 
Understanding a firm's activity assets will provide a basis for learning and exploiting strengths toward the achievement of performance goals.

Market sensing is a process that actively acquires and distributes information about the needs and responses of the market, such as how it is segmented and the intentions and abilities of competitors (Day, 1994a; Ramaswami et al., 2004). An organization that is adept at market sensing can identify trends more effectively than competitors and better respond to customer needs and desires (Ramaswami et al., 2004).

\section{BUSINESS PERFORMANCE}

Two performance measures, achievement of sales and profit objectives, are suggested as the dependent variable in this study. These have been used in previous marketing, strategy, and management studies.

It is critical for managers to be armed with up-to-date information on the performance of their firm. Financial results are one of many measures that are critical to determining if a firm's specific approaches to doing business are working. Drucker's (1954) "purpose of the business" is realized when a firm identifies the linkage between its strategic methods and profitability.

\section{DEFINITION OF TERMS}

\section{Learning Orientation}

Sinkula et al (1997) have conceptualized learning orientation (see Figure 1) in terms of commitment to learning, shared vision and/or purpose, and open-mindedness. The conceptualization of the learning orientation construct (Sinkula et al., 1997) is described as: first, commitment to learning is when companies recognize the value of understanding the cause and effects of their actions; second, open-mindedness is related to the concept of "unlearning" which is when organizations are proactive in rethinking long-term processes and beliefs about how they do business; third, shared vision provides a window into expectations, outcomes, and theories in use that an organization has defined. Shared vision also provides an organization with the ability to adapt around consistent and shared assumptions that enhance the potential of focused and positive responses to changes in the market environment and better business performance over the long-term. Supporting many of the same ideas that define a learning orientation, Srivastava (2011) states, "A talented and experienced workforce, a close relationship with the customer, a deep understanding of customer needs, a shared commitment to their success, and the ability to respond quickly to changing customer priorities are universally accepted as primary sources of competitive advantage." (p. 157)

\section{Competitive Advantage}

The sources of competitive advantage construct of Ramaswami et al. (2004) was used for this study and illustrated in Figure 1 and was conceptualized as follows: Development of Differentiated Products, Market Sensing, Market Responsiveness: Customers, Market Responsiveness: Competitors. Srivastava (2011), in his study management of innovation and technology, found that "If there is one place in which management and employees are in complete agreement, it is in the components of competitive advantage (p. 157).

\section{Business Performance}

A firm's success is measured by superior and sustainable performance, which is, in turn, measured by profits and return on investment (Hunt \& Morgan, 1996). A company's performance is influenced by intangible assets, such as learning and sources of competitive advantage, that affect the value-creating processes (Kaplan \& Norton, 2004). 


\section{Learning Orientation and Competitive Advantage}

Organizations need to learn what customers desire or need so that they can understand what it takes to create superior value and to have a competitive advantage in the marketplace (Hunt \& Morgan, 1996; Ramaswami et al., 2004). Customer defined value serves as a guiding force for deciding what to improve and knowing how to improve it (Woodruff \& Gardial, 1996). The delivery of customer value is an information intensive way of marketing, requiring adeptness at learning about customers (Woodruff \& Gardial, 1996) and their reasons for buying.

\section{Learning Orientation and Business Performance}

Learning orientation has a positive and significant impact on business performance (Baker \& Sinkula, 1999). Learning provides the opportunity for decisions to be made with an understanding of the myriad of variables and relationships with processes and the market that set the stage for making correct customer value, creating choices that leads to desirable business performance. Therefore, superior performance, in the long run, depends on learning excellence with a long-term systematic focus (Senge, 1990). Earlier findings of Sinkula et al (1997) conclude that and increase in learning orientation results in the long-run improvement in organizational performance. Later Baker and Sinkula $(1999,2000)$ and Slater and Narver (1999) show that there was a significant and positive relationship between learning orientation and organizational performance.

\section{FINDINGS}

Using the same data set as Martinette (2006) and Martinette and Obenchain-Leeson (2010), this research tested the earlier model incorporating pure service and service-reliant firms (figure 1). The following research questions and hypotheses were tested:

1. Is there an association between learning orientation and business performance - the achievement of sales and profit objectives in pure service and service-reliant organizations?

Ho1: There is no association between learning orientation and business performance in pure service and servicereliant organizations.

Ha1: There is an association between learning orientation and business performance pure service and servicereliant organizations.

\section{Analysis: Bivariate Correlation}

Choosing only organizations defined as pure service and service-reliant $(n=129)$, a simple bivariate correlation was calculated to assess the relationship between learning orientation and business performance variables. According to Table 1, the relationship was both positive and significant with a weak effect, $r(129)=.24, p$ $<.01$. Thus, as learning orientation increases in pure service and service-reliant organizations, business performance scores also increase. This suggests that approximately $5.8 \%$ of the change in business performance in small organizations is related to learning orientation.

The positive correlation found between learning orientation and business performance is not surprising. This relationship has been suggested by Senge (1990), and demonstrated by a variety of empirical studies (Baker \& Sinkula, 1999; Lopez, Peon and Ordas, 2005; Martinette, 2006; Martinette \& Obenchain, 2010). Additionally, it was expected that pure service and service-reliant organizations would clearly demonstrate a statistically significant relationship between learning orientation and business performance because the very heart of such organizations is an offering that is inseparable, in delivery, between the buyer and the seller. That is, built into the very heart of service creation and service delivery are key processes of information exchange, personal attention and relationship management between the buyer and seller. Perhaps it is the case that service organizations have a built in capability for learning and hence, better performance. 
Table 1: Bivariate Correlation Analysis of Learning Orientation and Business Performance in Pure Service and Service-reliant Organizations

\begin{tabular}{cc}
\hline & Service Organizations $(\mathbf{n}=\mathbf{1 2 9})$ \\
\hline Learning Orientation & Business Performance \\
\hline N $24 * 01$ & $.24 *$ \\
\hline
\end{tabular}

Note: $* * \mathrm{p}<.01$

2. Is there an association between learning orientation and competitive advantage in pure service and servicereliant organizations?

Ho2: There is no association between learning orientation and competitive advantage in pure service and servicereliant organizations.

Ha2: There is an association between learning orientation and competitive advantage in pure service and servicereliant organizations.

\section{Analysis: Bivariate Correlation}

Choosing only organizations defined as pure service and service-reliant $(n=129)$, a simple bivariate correlation was calculated to assess the relationship between learning orientation and competitive advantage variables. According to Table 2, the relationship was both positive and significant with a nearly moderate effect, $\mathrm{r}(129)=.48, \mathrm{p}<.01$. Thus, as learning orientation increases in pure service and service-reliant organizations, business performance scores also increase. This suggests that approximately $23 \%$ of the change in competitive advantage in service organizations is related to learning orientation.

The positive correlation found between learning orientation and business performance is not surprising. This relationship has been suggested by Senge (1990), and demonstrated by a variety of empirical studies (Baker \& Sinkula, 1999; Pemberton, Stonehouse \& Yarrow, 2001; Martinette, 2006; Martinette \& Obenchain, 2010). Additionally, it was expected that pure service and service-reliant organizations would demonstrate a statistically significant relationship between learning orientation and competitive advantage because buyers and sellers are connected as co-creators of value in the creation and delivery of services. This connectedness may allow better knowledge and understanding, resulting in new services and ways of doing business. As a result, superior growth and outcomes, particularly competitive advantage is possible

Table 2: Bivariate Correlation Analysis of Learning Orientation and Business Performance in Small and Large Organizations

\begin{tabular}{lc} 
& and Business Performance in Small and Large Organizations \\
\hline & Pure Service and Service-reliant Organizations \\
\hline Learning Orientation & Competitive Advantage \\
\hline Note: $* * \mathrm{p}<.01$ & $48^{* *}$ \\
\hline
\end{tabular}

3. Does competitive advantage moderate the relationship between learning orientation and business performance in pure service and service-reliant organizations?

Ho3: Competitive advantage has no effect on the relationship between learning orientation and business performance in pure service and service-reliant organizations.

Ha3: Competitive advantage has an effect on the relationship between learning orientation and business performance in pure service and service-reliant organizations.

\section{Analysis: Partial Bivariate Correlation}

To examine hypothesis 3, a partial correlation was conducted to assess if competitive advantage moderates the relationship between learning orientation and business performance in pure service and service-reliant 
organizations. First, multiplying the overall learning orientation scores and the overall competitive advantage scores created an interaction term. This created the new interaction term (LOXCA), which was used to assess if, taken together, the product of learning orientation and competitive advantage is associated to business performance.

Zero-order correlations - correlations without any control variables - are presented in Table 3 where positive and statistically significant relationships exist among all variables: learning orientation, competitive advantage, business performance and the interaction term (LOXCA).

Table 3: Zero Order Correlations among Learning Orientation (LO), Competitive Advantage (CA), Business Performance (BP) and the Interaction Term (LOXCA) in Pure Service and Service-reliant Organizations

\begin{tabular}{lllll}
\hline & LO & CA & BP & LOXCA \\
\hline LO & 1.0 & $.48^{* *}$ & $.24^{*}$ & $.86^{* *}$ \\
CA & -- & 1.0 & $.27^{* *}$ & $.85^{* *}$ \\
BP & -- & -- & 1.0 & $.28^{* *}$ \\
\hline
\end{tabular}

Note: $* * \mathrm{p}<.01$

To partition the independent variance of each variable, competitive advantage and learning orientation were entered as control variables. After controlling for the above variables, the interaction term (LOXCA) was significantly related to all three variables, learning orientation, business performance and competitive advantage. This correlation suggests that competitive advantage moderates the relationship between learning orientation and business performance in pure service and service-reliant organizations.

\section{RECOMMENDATIONS FOR FUTURE RESEARCH}

This research demonstrated a significant relationship between learning orientation and business performance, and between learning orientation and competitive advantage. The research also found that competitive advantage moderates the learning orientation business performance relationship. Future researchers may want to consider several possibilities.

First, researchers could target a more precise set of respondents by using a more targeted population. For example, surveys could be conducted that excluded top management and focused on front line workers, or researchers may want to have a large enough sample to make significant comparisons among the subgroups. Multiple companies in different industries could be surveyed in large enough numbers so as to provide context across service businesses.

Second, based on the previous research of Martinette (2006), and Martinette and Obenchain (2010), it is clear that a focus on service organizations provided support for the theoretical model of this study. However, to further validate this finding, this study could be replicated in specific service industries.

Third, researchers could consider learning orientation and process issues. Both marketing and process thinkers suggest the need for a learning orientation.

Woodruff (1997) sums up the relationships that he believes should be considered in the creation of customer value by stating, "...managers must translate customer learning into superior performance with customers. For instance, an organization's internal process for delivering value must be brought in line with a customer's value" (p. 140). This requires a coordinated effort to capture and disseminate information throughout the organization (Woodruff, 1997).

Fourth, researchers could study the impact of strategy on the learning orientation business performance relationship. Superior performance, in the long run, depends on learning excellence (Senge, 1990) with a long-term systematic focus. Learning provides the opportunity for decisions to be made with an understanding of the myriad of variables and relationships with processes and the market that set the stage for making correct customer value creating choices that leads to desirable business performance. Scholars have noted that the ability to implement 
strategy is likely more important than the actual strategy (Kaplan \& Norton, 2001). Kaplan and Norton (2001) add, "The feedback and review of strategic information helps to maintain enthusiasm about the strategic journey and to guide the organization to ever-higher levels of performance" (p. 328).

Fifth, it would be useful for researchers to develop the relationship between customer value and competitive advantage. The literature stream on value consistently connects to how, why, and for whom products are made. The study of value is grounded in the theories of customer satisfaction, competitive superiority/advantage, and service/quality (Day \& Wemsley, 1988; Woodruff, 1997; Zeithaml, 1988).

\section{MANAGERIAL IMPLICATIONS}

The findings of this study demonstrated a positive relationship between learning orientation and firm performance, and learning orientation and competitive advantage, consistent with previous literature. Managers seeking improved business performance through learning orientation need to gain organizational commitment to learning, spread a shared vision and purpose across the organization, and develop a culture of open-mindedness.

The moderating influence of competitive advantage on the learning orientation and firm performance relationship was demonstrated as suggested by hypothesis three. The results could indicate that because service firms with an established record of having a competitive advantage in their respective markets may emerge as the dominant force when environmental changes occur, suggesting that they link environmental trends to the key components of organizational learning.

The results of this study should provide a useful model that will help managers in their focus on investing in and enhancing their approach to learning and how they view a competitive advantage in the context of a changing market environment. This model is illustrated in many ways.

First, this research suggests that managers and scholars need to learn that firms must exploit competitive advantage while fully integrating an organization's commitment to learning and shared vision/purpose. The importance of learning was emphasized by Strata (1989), the chairman of Analog Devises, when he strongly suggested that learning is a major source of competitive advantage. That belief coupled with the rapid changes in product offerings and market environments enabled by information technology suggests that learning "...may become the only viable alternative to corporate extinction" (Kiernan, 1993, p. 9).

Second, the research also suggests that the nature of resources in a service-reliant firm is primarily made up of intangible assets. In the 1990s, the grocery chain Food Lion provided another example of a firm that failed to match its competitive advantage of low cost/low price to the prevailing desires of the market which were more related to differentiation (Dess \& Picken, 1999). Food Lion management could learn from Wal-Mart's success. Organizational learning, unlike individual learning, depends on shared insights and past knowledge (Stata, 1989) and does not just happen in a vacuum.

Third, this research also suggests that Kaplan and Norton's (2001) later proposition that competitive advantage comes from the effective use of knowledge, capabilities and relationships is valid. Kaplan and Norton (2001) stated: "Large organizations can gain advantage from their scale by identifying and sharing their large information of knowledge and experience. For this to occur, however, they must promote a culture of information sharing." (pp. 324-325) How a marketer uses the knowledge gained from learning is addressed by Woodruff and Gardial (1996): "While every organization has some processes in place for this purpose, we believe they can be improved substantially. Most managers with whom we talked agree. The question is how to improve these processes?" (p. 12).

The way that customers define value evolves into the guiding force for deciding what to improve (Woodruff \& Gardial, 1996) and knowing how to improve it. Organizational learning and the innovations that can result from the knowledge gained, helps a company "create a future" by "unlearning its past" (Hamel \& Prahalad, 1994), opening the door to a new view of markets, what that translates into for the employee and the customer in terms of the processes that are used to create, manufacture, and deliver value. As a font of experiences, an 
organization's people are in contact with customers (both old and new), competitor information, and problem solving, each of which provides ample opportunity to learn new ideas from "each and every incremental experience" for improving and innovating (Hamel \& Prahalad, 1994).

Fourth, the idea of gaining a marketplace advantage is not new to marketers, both practitioners and researchers, and the idea of gaining a competitive advantage remains a driving force for organizations. The findings of this research indicated that having a competitive advantage did not impact the learning orientation business performance relationship. While most organizations gain competitive advantage by building products that are desired by targeted customers knowing that creating value is a two-way street, it is critical to integrate the marketer and the customer into an effective information exchanging entity. However, a marketer needs to constantly be inquiring about the needs of their target customer while making it easy for the customer to provide the information needed to reflect their desires and encouraging an organization that positively controls and manages that valuable customer information.

Fifth, these findings suggest that organizations with a learning orientation should focus on exploiting and enhancing their existing competitive advantages in order to maintain a positive and significant relationship with business performance.

\section{AUTHOR INFORMATION}

Dr. Louis Martinette is an associate professor of Management and Marketing at the University of Mary Washington. Dr. Martinette has authored and presented research papers at the Hawaii International Conference on Business, the International Conference of Global Management Studies, the International Academy of E-Business, and the Economics and Business Research Conference. Dr. Martinette has been a guest speaker at the Stafford County Government Economic Forum. Dr. Martinette's business experience includes both sales and marketing in leadership positions at 3M Company, as a partner and an officer in two smaller firms, and has consulted on strategic planning projects with Chesapeake Forest Products Company, Imation, Landmark Communications, and Charles M. Schulz (the creator of Peanuts) Creative Associates. E-mail: docmartinette@me.com. Corresponding author.

Dr. Alice Obenchain Leeson is an Associate Professor of Business Administration at Averett University. She is an active researcher in the fields of organizational culture and organizational innovation, perceived value, and teaching methodologies. She has published in the Journal of Applied Management and Entrepreneurship, and the Journal of Christian Higher Education and the Liberty Business Review. She is currently a reviewer for the Academy of Management Annual Meetings, and was recognized as an Outstanding Reviewer for 2008. In addition, she has authored and presented research papers at the Hawaii International Conference on Business, the Consortium for the Advancement of Adult Higher Education and the Annual Conference of the Association of Continuing Higher Education. E-mail: aliceo@averett.edu

\section{REFERENCES}

1. Adams, Scott. (2011), How to create a fake vacation, June 18, 2011, The Wall Street Journal Online Edition.

2. Argyris, C. (1977). Double loop learning in organizations. Harvard Business Review, 55(SeptemberOctober), 115-125.

3. Argyris, C. (1991), Teaching smart people how to learn. Harvard Business Review, 69 (May/June), 99-109.

4. Baker, W. E. \& Sinkula, J. M. (1999). The synergistic effect of market orientation and learning orientation on organizational performance. Journal of the Academy of Marketing Science, 24(4), 411-427.

5. Baker, W. E. \& Sinkula, J. M. (2000). Market orientation, learning orientation, and product innovation: Delving into the black box. Journal of Market-Focused Management, 5, 5-23.

6. Bolman, L. G. \& Deal, T. E. (2003). Reframing organizations: Artistry, choice, and leadership (3rd ed.). California: Jossey-Bass.

7. Collins, J. (2001). Good to great: Why some companies make the leap ... and others don't. New York: Harper Business.

8. Cravens, D. W. \& Piercy, N. F. (2006). Strategic marketing ( $8^{\text {th }}$ edition). New York: McGraw-Hill Irwin. 
9. Day, G. S. (1991). Learning about markets. Marketing Science Institute. Report \# 91-117, June.

10. Day, G. S. (1994a). The capabilities of market-driven organizations. Journal of Marketing, 58(4), 37-52.

11. Day, G.S. (1994b). Continuous learning about markets. California Management Review 36, (Summer), 931.

12. Day, G. S. \& Wensley, R. (1988). Assessing advantage: A framework for diagnosing competitive superiority. Journal of Marketing, 52 (April), 1-20.

13. deGues, A. (1988). Planning as learning. Harvard Business Review, 66 (March-April), 70-74.

14. DeLong, Thomas \& Nanda, Ashis (2003). Professional services: text and cases. McGraw-Hill, Irwin.

15. Dess, G. G., \& Picken, J. C. (1999). Creating competitive (dis)advantage: learning from food lion's freefall. Academy of Management Executive, 13(3), 97-111.

16. Dickson, P. R. (1996). The Static and dynamic mechanics of competition: a comment on Hunt and Morgan's comparative advantage theory. Journal of Marketing, 60, (October), 102-106.

17. Drucker, P. (1954). The practice of management. New York: Harper \& Row.

18. Fiol, C. M. \& Lyles, M. A. (1985). Organizational learning. Academy of Management Review, 10, (October), 803-813.

19. Garvin, D. A. (1993). Building a learning organization. Harvard Business Review (July-August), $78-91$.

20. Gronroos, Christian (2000). Service management and marketing: A customer relationship management approach. Hoboken, NJ: John Wiley \& Sons.

21. Gronroos, Christian (2008). Service logic revisited: who creates value? And who co-creates? European Business Review, 20, (4), 298-314.

22. Hamel, G. \& Prahalad, C. K. (1994). Competing for the future. Massachusetts: Harvard Business School Press.

23. Huber, G. P. (1991). Organizational learning: the contributing processes and the literatures. Organizational Science, 2 (February), 88-115.

24. Hunt, S. D. \& Morgan, R. M. (1996). The Resource-advantage theory of competition: dynamics, path dependencies, and evolutionary dimensions. Journal of Marketing, 60 (October), 107-114.

25. Kaplan, R. S. \& Norton, D. P. (1996). Translating strategy into action: the balanced scorecard. Boston: Harvard Business School Press.

26. Kaplan, R. S. \& Norton, D. P. (2001). The strategy-focused organization: how balanced scorecard organizations thrive in the new business environment. Boston: Harvard Business School Press.

27. Kaplan, R. S. \& Norton, D. P. (2004, February). Measuring the strategic readiness of intangible assets. Harvard Business Review, 82 (2), 52-63.

28. Kohli, A. K. \& Jaworski, B. (1990). Market orientation: the construct, research, propositions, and managerial implications. Journal of Marketing, 54 (April), 1-18.

29. Kiernan, M. (1993). The new strategic architecture: Learning to compete in the twenty- first century. Academy of Management Executive, 7 (1), 7-21.

30. Levitt, B. \& March, J. G. (1988). Organizational learning. Annual Review of Sociology, W. Richard Scott and Judith Blake, eds. Palo Alto, CA: Annual Reviews, Inc., 319-40.

31. Lopez, S., Peon, J., \& Ordas, C. (2005). Organizational learning as a determining factor in business performance. The Learning Organization, 12(3), 227-245.

32. Martinette, Louis A. (2006). The relationship between learning orientation and business performance: the moderating effect of sources of competitive advantage. Dissertation.

33. Martinette, Louis A. \& Obenchain-Leeson, Alice (2010). A view based on organizational size: how competitive advantage moderates the learning orientation/business performance relationship. International Journal of Global Management Studies, 1 (4).

34. Moorman, C. \& Rust, R. T. (1999). The role of marketing. Journal of Marketing, 63, Special Issue, 180197.

35. Ovide, Shira. (2011), Winners and losers from the week in business, June 17, 2011, The Wall Street Journal Online Edition.

36. Pemberton, J., Stonehouse, G., \& Yarrow, D. (2001). Benchmarking and the role of organizational learning in developing competitive advantage. Knowledge and Process Management, 8(2), 123-135.

37. Porter, M. (1985). Competitive advantage: Creating and sustaining superior performance. New York: The Free Press. 
38. Ramaswami, S. N., Bhargava, M. \& Srivastava, R. (2004). Market-based assets and capabilities, business processes, and financial performance. Marketing Science Institute Report (04-102). Issue One, Working Paper Series.

39. Senge, P. (1990). The leader's new work: building learning organizations. Sloan Management Review, 32(1), 7-23.

40. $\quad$ Senge, P. (1992). Mental models. Planning Review, 20, 4-10.

41. Sinkula, J.M., Baker, W. E., \& Noordewier, T. (1997). A framework for market-based organizational learning: linking values, knowledge, and behavior. Journal of the Academy of Marketing Science, 25(4), 305-318.

42. Slater, S. F. \& Narver, J. C. (1994a). Does competitive environment moderate the market orientationperformance relationship? Journal of Marketing, 58, 46-55.

43. Slater, S. F. \& Narver, J. C. (1994b). Market oriented is not enough: build a learning organization. Marketing Science Institute Report \#94-103, Sage Publications.

44. Slater, S. F. \& Narver, J. C. (1995). Market orientation and the learning organization. Journal of Marketing, 59, 63-74.

45. Srivastava, Mukesh (2011). A case study and survey-based assessment of the management of innovation and technology. Journal of Technology Management and Innovation, 6 (1), 47-60.

46. Stata, R. (1989). Organizational learning: The key to management innovation. Sloan Management Review, 30, 63-74.

47. Ussahawanitchakit, Phapruke (2008). Effects of organizational learning culture on service quality and performance of Thai accounting firms. International Journal of Business Research, Vol. 8, No. 1, 202-211

48. Woodruff, R. B. \& Gardial, S. F. (1996). Know your customer: new approaches to understanding customer value And Satisfaction. Malden, MA: Blackwell Publishers Limited.

49. Woodruff, R. (1997). Customer value: The next source for competitive advantage. Journal of the Academy of Marketing Science, 25(2), 139-153.

50. Zeithaml, V. (1988). Consumers perception of price, quality, and value: A means-end model and synthesis of evidence, Journal of Marketing, 52 (July), 2-22.

51. Zikmund, W. (2003). Business Research Methods. Boston: Thomson. 